\title{
TRANSPLANTING USING PAPER POTS TECHNIQUE AND MICRO NUTRITION WITH RELATION TO YIELD AND IT'S ATTRIBUTES OF SUGAR BEET AT DIFFERENT PLANTING DATES
}

\author{
EL-GEDDAWY, I. ${ }^{1}$, M.S. OSMAN ${ }^{2}$, M.G.A.TAHA ${ }^{2}$ AND S. A. A. M. ENAN ${ }^{1}$
}

1 Sugar Crops Res. Inst., ARC, Giza, Egypt

2 Agron. Dept Fac. Agric, ALAzhar Univ.

(Manuscript received 16 January 2006)

Abstract

Two field experiments were conducted in 2001/2002 and 2002/2003 seasons at Sakha Agricultural Research Station, Kafr-El Sheikh Governorate to study the effect of transplanting technique and soil application of boron and zinc on yield and its components of sugar beet crop sown at two dates.

The present work included twenty treatments represent the combination between five sowing technique of sugar beet (1.Sowing sugar beet by dried seeds-direct sown, 2. Transplanting by paper pots seedling of 15 days age, 3.Transplanting by paper pots seedling of 25 days age, 4.Transplanting by paper pots seedling of 35 days age, 5 . Transplanting by seedling resulted from the permanent field at thinning time.) and four micro-nutrient treatments i.e. : Unfertilized treatment as control, $0.5 \mathrm{~kg}$ boron/fed "recommended dose", $4.0 \mathrm{~kg}$ zinc/fed " recommended dose" and $0.5 \mathrm{~kg}$ boron $+4.0 \mathrm{~kg}$ zinc/fed.). All treatments were applied for sugar beet sown at two sowing dates $\left(15^{\text {th }}\right.$ September and $15^{\text {th }}$ October).

The obtained results showed that sowing sugar beet early on $15^{\text {th }}$ September significantly attained higher values of growth traits as well as sugar recovery \%, root, top and sugar yields/fed compared with that of $15^{\text {th }}$ October. Total number of roots/fed and abnormal root $\%$ were insignificantly affected by sowing dates.

Sowing sugar beet by using paper pots seedlings of 15 days age produced the highest and significant values of growth traits, total root numbers/fed, as well as root top and sugar yields/fed and gave the lowest value of abnormal root \%.

The results showed that the application of zinc element alone or in combination with boron element significantly resulted in higher values of root length, root diameter, top yield/fed compared with those recorded by unfertilized or applied with boron only. Application of boron alone or in combination with zinc produced higher root fresh weight/plant, sugar recovery $\%$ as well as root and sugar yields/fed compared with those recorded by the unfertilized or applied with zinc alone.

\section{INTRODUCTION}

Sugar beet is considered the second sugar crop in sugar production in the world and in Egypt as well. There are many factors affecting yield and quality of sugar beet such as some of agro practices, i.e. sowing dates, sowing methods and the 
application of micro-elements. Concerning sowing dates, determining the appropriate sowing date depends, to a great extent, on the prevailing climatic conditions along the growing season. In Egypt, sugar beet is sown during the period extends from August to November. As for sowing methods, transplanting is a practice commonly used for adjusting plant stand per unit area exposed to damage by agricultural practices as hoeing or by diseases or insects during growing season, leading to raising numbers of harvestable plants. Regarding trace elements which are essential for plant growth and metabolism, boron and zinc are the most important ones needed by sugar beet, where yield and quality of roots are severely depressed by its inadequate supply. (Draycott, 1993). In this respect, Azzazy (1998), found that sowing date of sugar beet (November $1^{\text {st }}$ and November $15^{\text {th }}$ ) in Egypt insignificantly affected root yield, sugar yield and purity percentage. Top yield was significantly affected by sowing date in the first and second season. Ramadan and Hassanin (1999), evaluated six sugar beet genotypes (Sofi, Maghribel, Desperez polu-n, Marathon, Pamela and Eva) grown at three sowing dates ( $10^{\text {th }}$ September, $12^{\text {th }}$ October and $10^{\text {th }}$ November). They found that early planting was accompanied with substantial increase in root length, root diameter, root weight, sugar content, purity, sugar percentage. Moreover, early planting was accompanied by substantial decrease in impurities and sucrose loss to molasses. Al-Jbawi (2000), found that sowing date revealed significant effect on quality traits (T.S.S) \%, sucrose and purity $\%$ and root traits (length, diameter and weight). Quality traits, or root traits in general, were reduced with the delay in planting. Abd El-Aal (2001), found that delaying sugar beet planting date one month from mid-Sep. to mid-Oct. decreased root yield ton/fed., by about $7.22 \%$ and dropped on mid-Nov. planting to $27.47 \%$ compared with the early planting date. He also added that Sep. (early) planting along with Oct. (middle) planting date gave the higher sugar yield and out yielded that of Nov. (late) planting by $21.8 \%$ and $17.5 \%$ respectively. Abou salama and El-sayed (2001), compared sowing dates on $1^{\text {st }}$ and $15^{\text {th }}$ October and $1^{\text {st }}$ November, they found that mean root yield was $31.64,18.73$ and $11.51 \mathrm{t} / \mathrm{fed}$ from the three dates, respectively. As for sowing methods, El-Geddawy et al. (1997), in their trail using combination between the two transplanting methods (from the nursery and by using paper pots) and three plant ages, (2, 4 and 6 leaf stages) in addition to control (direct seed bed), concluded that the highest response in root dimensions were attained with the direct sowing method. However, the highest figures of root dimensions were recorded by using paper pots when sugar beet seedlings grown at 2-leaf stage. Transplanting sugar beet seedlings by using paper pots of 2-leaf stage attained the lowest values of the branched roots (0.6-1\%). Abd El-Gawad et al. (2000), cleared that transplanting of transplants at age of 5, 7 and 9 
weeks as well as direct seedling markedly increased number of harvestable plants and abnormal root $\%$ as compared with direct seedling. Root dimensions were considerably affected whereas length and root diameter of direct seedling treatments were greater than those of transplanting treatments. The average fresh weight of sugar beet roots of direct seedling planting was higher than those cbtained from transplanting treatments. El-Debaby et al. (2003), cleared that transplanting caused a considerable increased in plant population as compared with direct sowing, top, root, biological and sugar yield/fed., were significantly higher with transplanted plant than direct sown ones. Moreover, two true leaves transplants produced the highest value of top, root, biological and sugar yield followed by direct sown then four true leaves transplanting. Regarding the effect of micro-elements, Saif (1991), mentioned that soil application of $0.5 \mathrm{~kg} \mathrm{~B} / \mathrm{fed}$ and $4 \mathrm{~kg} \mathrm{Zn/fed} \mathrm{gave} \mathrm{the} \mathrm{highest} \mathrm{values} \mathrm{leaves} \mathrm{number,}$ tops fresh and dry weights/plant as well as fresh and dry weights of roots, both root length and diameter, sucrose, T.S.S and purity percentages, produced a significant increase in yields of tops, roots and sugar tons/fed. Elwan et al. (2001), indicated that $\mathrm{Zn}$ was more effective than $\mathrm{Cu}$ on total fresh and dry weights. He also reported that chlorophyll content was increased by zinc treatments. Osman, et al. (2003), applied sugar beet plants with three boron level (zero, 1 and $2 \mathrm{~kg} \mathrm{B/fed.)} \mathrm{they} \mathrm{found} \mathrm{that}$ increasing the level of boron up to $2 \mathrm{~kg} / \mathrm{fed}$., increased leaf area index (LAI), total dry weight, assimilation rate, root/top ratio, root length, sucrose and purity percentages as well as sugar yield (ton/fed).

\section{MATERIALS AND METHODS}

Two field experiments were conducted in two successive seasons of 2001/2002 and 2002/2003 at Sakha Agricultural Research Station, (Kafr-El Sheikh Governorate), these experiments were conducted to study the effect of transplanting technique and soil application of boron and zinc on growth, yield and quality of sugar beet crop (Beta vulgaris L.)

Physical and chemical properties of the experimental soil are presented in (Table 1). Meteorological data in 2001/2002 and 2002/2003 seasons are recorded in (Table 2).

The present work included twenty treatments, which were the combination between five sowing techniques of sugar beet, and four micro-element treatments (boron and zinc). These treatments were carried out in two sowing dates.

\section{Sowing dates:}

* $15^{\text {th }}$ September.

$* 15^{\text {th }}$ October. 


\section{Transplanting techniques:}

1. Sowing sugar beet by dried seeds (direct sown).

2. Transplanting by paper pots seedling of 15 days age.

3. Transplanting by paper pots seedling of 25 days age.

4. Transplanting by paper pots seedling of 35 days age.

5. Transplanting by seedling resulted from the permanent field at thinning time.

\section{IIr. Micro-nutrient treatments:}

1. Unfertilized treatments (control).

2. $0.5 \mathrm{~kg}$ boron/fed. (Recommended dose).

$3.4 .0 \mathrm{~kg}$ zinc/fed. (Recommended dose).

4. $0.5 \mathrm{~kg}$ boron $+4.0 \mathrm{~kg}$ zinc/fed.

Boron was applied as sodium borate $(11 \% \mathrm{~B})$, and zinc was added as zinc sulfate (22\% Zn).

The studied micro-nutrient treatments were applied once either singly or mixed with the $2^{\text {nd }}$ dose of nitrogen fertilizer (one month later after the $1^{\text {st }}$ dose of nitrogen fertilizer). As a soil application after complete mixing doses properly with appropriate amounts of sand.

A recommended dose of nitrogen fertilizer ( $80 \mathrm{~kg} \mathrm{~N} /$ fed.). in the form of urea $(46 \% \mathrm{~N})$ was applied in two equal doses, $1^{\text {st }}$ dose after thinning and the $2^{\text {nd }}$ dose one month later. $\mathrm{A}$ recommended dose of potassium ( $48 \mathrm{~kg} \mathrm{~K} 2 \mathrm{O} /$ fed.) in the form of potassium sulphate $48 \%$ $\mathrm{K}_{2} \mathrm{O}$ was added once with the $1^{\text {st }}$ dose of nitrogen. Meanwhile phosphorus fertilizer was applied as recommended at the rate of $\left(30 \mathrm{~kg} \mathrm{P}_{2} \mathrm{O}_{5} / \mathrm{fed}\right.$.) in the form of calcium super phosphate $15.5 \% \mathrm{P}_{2} \mathrm{O}_{5}$ during land preparation.

The twenty treatments combination among the studied factors, i.e. seedling age and trace elements were distributed in a complete randomized block design in three replications at each of the studied two sowing dates. Plot area was $15.4 \mathrm{~m}^{2}$, which included 4 ridges, 7 meter in length and 2.2 meter in width.

Plants were thinned at 4-leaf stage (almost 45 days from sowing) to ensure one plant per hill. Other agronomic practices required for growing sugar beet were practiced as usual. The seeds and paper pots were sown at $20 \mathrm{~cm}$. between hills, the commercial sugar beet variety Gazelle (imported from Denmark by Sugar Crops Inst.) was used in the two seasons. Beet plants were harvested at maturity after seven months in both seasons according sowing date. 
Table 1. Meteorological data for Kafer El sheik Governorate in 2001/2002 and 2002/2003 growing seasons.

\begin{tabular}{|c|c|c|c|c|c|c|c|c|c|}
\hline \multirow{3}{*}{ Month } & \multirow{3}{*}{ Day } & \multicolumn{4}{|c|}{ 2001-2002 } & \multicolumn{4}{|c|}{$2002-2003$} \\
\hline & & \multicolumn{2}{|c|}{ Temperature $\mathrm{C}^{0}$} & \multicolumn{2}{|c|}{$\begin{array}{c}\text { Relative humidity } \\
\%\end{array}$} & \multicolumn{2}{|c|}{ Temperature $C^{\circ}$} & \multicolumn{2}{|c|}{$\begin{array}{c}\text { Relative humidity } \\
\quad \%\end{array}$} \\
\hline & & Max. & Min. & Max. & Min. & Max. & Min. & Max. & Min. \\
\hline \multirow{3}{*}{ September } & $1-15$ & 31.40 & 19.62 & 92.50 & 38.40 & 32.60 & 20.00 & 95.10 & 37.20 \\
\hline & $16-30$ & 30.60 & 18.38 & 91.50 & 41.60 & 33.60 & 19.60 & 94.90 & 30.80 \\
\hline & Average & 31.00 & 19.00 & 92.00 & 40.00 & 33.10 & 19.80 & 95.00 & 34.00 \\
\hline \multirow{3}{*}{ October } & 1-15 & 28.90 & 15.75 & 95.35 & 38.10 & 29.47 & 17.90 & 94.25 & 41.00 \\
\hline & $16-31$ & 25.90 & 14.25 & 94.65 & 39.90 & 27.13 & 16.10 & 93.75 & 47.00 \\
\hline & Average & 27.40 & 15.00 & 95.00 & 39.00 & 28.30 & 17.00 & 94.00 & 44.00 \\
\hline \multirow{3}{*}{ November } & 1-15 & 24.30 & 12.32 & 93.85 & 41.50 & 25.20 & 12.81 & 94.90 & 41.93 \\
\hline & $16-30$ & 20.70 & 11.08 & 86.15 & 40.50 & 25.60 & 12.79 & 95.10 & 42.07 \\
\hline & Average & 22.50 & 11.70 & 90.00 & 41.00 & 25.40 & 12.80 & 95.00 & 42.00 \\
\hline \multirow{3}{*}{ December } & 1-15 & 17.46 & 7.69 & 93.50 & 51.55 & 20.96 & 9.67 & 94.80 & 46.25 \\
\hline & $16-31$ & 17.94 & 6.11 & 96.50 & 44.45 & 18.84 & 8.93 & 95.20 & 49.75 \\
\hline & Average & 17.70 & 6.90 & 95.00 & 48.00 & 19.90 & 9.30 & 95.00 & 48.00 \\
\hline \multirow{3}{*}{ January } & $1-15$ & 13.69 & 4.47 & 94.20 & 49.20 & 20.82 & 8.60 & 93.60 & 44.20 \\
\hline & $16-31$ & 16.91 & 4.93 & 95.80 & 48.80 & 19.18 & 7.40 & 94.40 & 45.80 \\
\hline & Average & 15.30 & 4.70 & 95.00 & 49.00 & 20.00 & 8.00 & 94.00 & 45.00 \\
\hline \multirow{3}{*}{ February } & $1-15$ & 17.13 & 6.87 & 89.00 & 58.77 & 17.87 & 6.55 & 93.15 & 45.60 \\
\hline & $16-28$ & 18.07 & 7.33 & 94.00 & 47.23 & 15.53 & 7.25 & 94.85 & 46.40 \\
\hline & Average & 17.60 & 7.10 & 91.50 & 53.00 & 16.70 & 6.90 & 94.00 & 46.00 \\
\hline \multirow{3}{*}{ March } & $1-15$ & 20.80 & 7.60 & 94.95 & 41.25 & 21.96 & 9.73 & 96.08 & 41.00 \\
\hline & $16-31$ & 18.80 & 7.40 & 95.05 & 42.75 & 20.24 & 9.27 & 95.92 & 43.00 \\
\hline & Average & 19.80 & 7.50 & 95.00 & 42.00 & 21.10 & 9.50 & 96.00 & 42.00 \\
\hline \multirow{3}{*}{ April } & $1-15$ & 23.77 & 10.50 & 89.33 & 34.00 & 24.26 & 11.15 & 95.23 & 38.80 \\
\hline & $16-30$ & 23.83 & 11.30 & 94.67 & 38.00 & 24.14 & 11.85 & 94.77 & 35.20 \\
\hline & Average & 23.80 & 10.90 & 92.00 & 36.00 & 24.20 & 11.50 & 95.00 & 37.00 \\
\hline \multirow{3}{*}{ May } & 1-15 & 28.60 & 14.25 & 94.92 & 30.20 & 29.77 & 15.88 & 94.94 & 28.08 \\
\hline & $16-30$ & 27.20 & 16.35 & 93.08 & 33.80 & 29.83 & 17.92 & 95.06 & 33.92 \\
\hline & Average & 27.90 & 15.30 & 94.00 & 32.00 & 29.80 & 16.90 & 95.00 & 31.00 \\
\hline
\end{tabular}

Source: Central Laboratory for Agricultural Climate, Agricultural Research Center, Giza, Egypt. 
Table 2. Physical and chemical properties of the site soil.

\begin{tabular}{|c|c|c|}
\hline Analysis & \multicolumn{2}{|c|}{ Seasons } \\
\hline & $2001 / 2002$ & $2002 / 2003$ \\
\hline \multicolumn{3}{|c|}{ Mechanical analysis } \\
\hline Coarse sand $(\%)$ & 1.25 & 1.42 \\
\hline Fine sand $(\%)$ & 14.52 & 17.0 \\
\hline Silt (\%) & 26.15 & 22.28 \\
\hline Clay (\%) & 57.78 & 59.30 \\
\hline Texture & Clay & Clay \\
\hline $\mathrm{CaCO}_{3}$ & 2.40 & 2.18 \\
\hline \multicolumn{3}{|c|}{ Chemical analysis } \\
\hline Organic Matter (\%) & 1.53 & 1.75 \\
\hline Available nitrogen ppm & 37.20 & 40.40 \\
\hline $\begin{array}{c}\text { Available phosphorus ppm } \\
\text { (Jackson, 1958) }\end{array}$ & 19.2 & 20.8 \\
\hline Available potassium ppm & 405.2 & 395.4 \\
\hline $\mathrm{pH}$ & 8.2 & 8.2 \\
\hline E.C ds $/ \mathrm{m}$ & 1.45 & 1.40 \\
\hline \multicolumn{3}{|c|}{ Cations \& Anions, meq/L } \\
\hline $\mathrm{Na}^{+}$ & 8.98 & 9.56 \\
\hline $\mathrm{K}^{+}$ & 0.21 & 0.23 \\
\hline $\mathrm{Ca}^{++}$ & 3.9 & 3.8 \\
\hline $\mathrm{Mg}^{++}$ & 2.5 & 2.6 \\
\hline $\mathrm{HCO}_{3}{ }^{-} \mathrm{meq} / \mathrm{L}$ & 5.58 & 5.09 \\
\hline $\mathrm{Cl}^{-}$ & 6.36 & 6.87 \\
\hline $\mathrm{SO}_{4}^{-2}$ & 3.65 & 4.23 \\
\hline \multicolumn{3}{|c|}{ Determined micronutrients $(p p m)$} \\
\hline $\mathrm{Fe}$ & 15.2 & 14.5 \\
\hline $\mathrm{Mn}$ & 18.3 & 17.6 \\
\hline $\mathrm{Zn}$ & 1.21 & 1.02 \\
\hline $\mathrm{B}$ & 0.41 & 0.45 \\
\hline
\end{tabular}

The recorded data:

Growth traits:

1. Root length $(\mathrm{cm})$.

Was measured from the basic part of the root till the tip.

2. Root diameter $(\mathrm{cm})$.

Was measured in the middle part of the root.

3. Root fresh weight (plant).

4. Top fresh weight (plant). 


\section{Yield and its components:}

At harvest, plants of four guarded rows from each treatment were uprooted and topped to determine the following parameters:

1. Total root numbers per feddan

2. Abnormal (branched) root percentage.

3. Top yield (ton/fed).

4. Root yield (ton/fed).

5. Sugar recovery percentage.

6. Sugar yield (ton/fed) was calculated according the following Equation:

Sugar yield $($ ton/fed $)=$ Root Yield $($ ton/fed $) \times$ sugar recovery percentage.

\section{STATISTICAL ANALYSIS}

Data collected were subjected to the proper statistical analysis of variance of complete randomized block design according to the procedures outlined by Snedecor and Cochran (1967).

A combined analysis of the two sowing dates in the two years was done according to Le Clerg et al(1966).

All statistical analysis was performed by using analysis of variance technique of (MSTAT) Computer software package.

\section{RESULTS AND DISCUSSION}

\section{Growth traits:}

\section{Root length.}

Sowing sugar beet early on the $15^{\text {th }}$ September attained The highest value of root length $(32.19 \mathrm{~cm})$ compared with that obtained at late sowing date $15^{\text {th }}$ October $(30.49 \mathrm{~cm})$. It could be noted that the pronounced effect of the early sowing date is mainly due to the enhanced influence of temperature degrees (Table 2 ) to the rapid growth, which in turn reflected on plant growth. This finding is in agreement with that reported by Ramadan and Hassanin (1999), and Al-Jbawi (2000) who reported that the taller root length was produced from the early sowing date (Mid-September compared with the late one Mid-November).

Sowing sugar beet by using paper pots seedling of 15 days age produced the highest significant value of root length compared with that recorded by sowing by the direct seeds and/or by the others paper pots seedling of the different ages. This result may be due to the relative advantage of the early transplanting for the seedling, delaying the age of the transplanted seedling gradually decreased root length. The negative effect of transplanted seedling with respect to this trait may be due to the 
abnormal growth of the sugar beet roots as a result to the mortality of the apical meristem, which may be delayed, the natural growth of the root.

Results obtained in Table (3) obviously show that all microelements treatments surpassed check treatments (control). This fact reassures the distinct influence of boron and zinc elements on plant growth. Moreover, the highest value of root length was produced from the mixture treatment (boron + zinc) followed by zinc treatment then boron treatment. It is well known the important role of zinc with respect to Tryptophan assimilation consequently, Auxin production which has a direct effect on plant growth.

Table 3. Effect of transplanting and soil application of boron and zinc on root length and root diametrer (cm/plant) in 2001-2002 and 2002-2003 seasons. (Combined over two seasons)

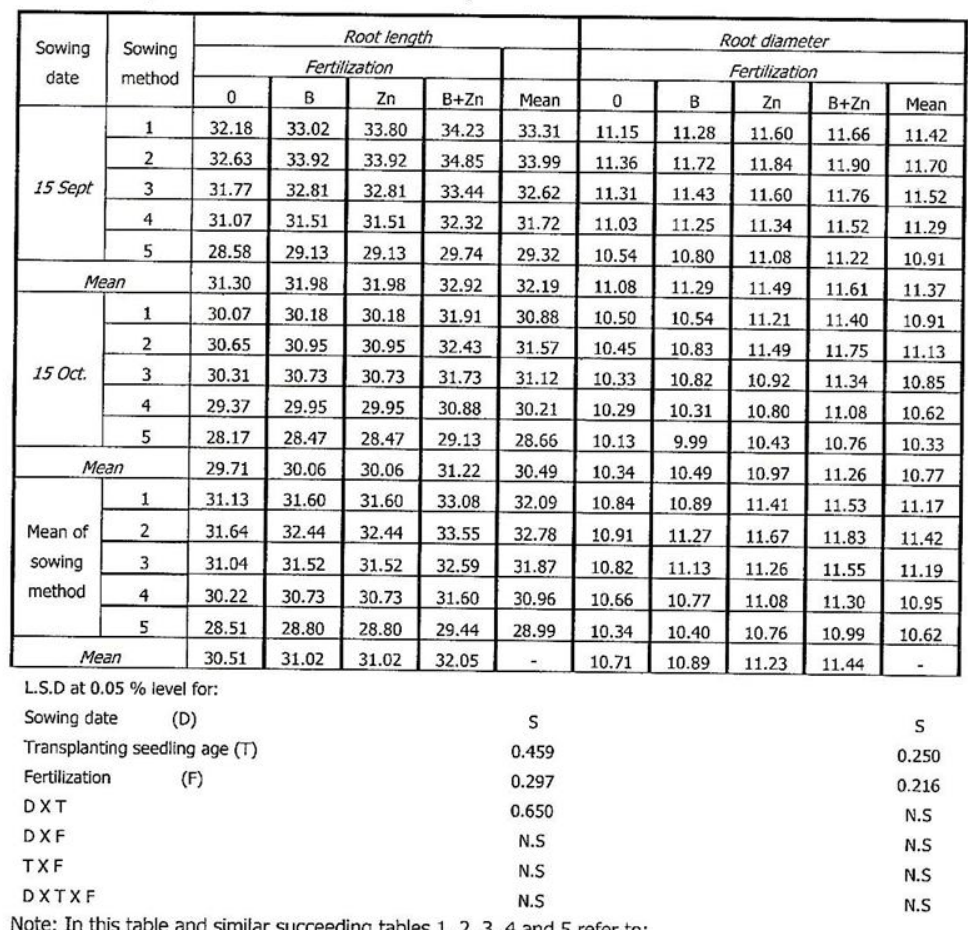

Note: In this table and similar succeeding tables 1, 2, 3, 4 and 5 refer to:

1 . sowing sugar beet by dried seeds.

2- transplanting by paper pots seedling of 15 days age.

3- transplanting by paper pots seedling of 25 days age.

4- transplanting by paper pots seedling of 35 days age.

5- transplanting by seedling resulted from the permanent field at thinning time. 
With regarded to interaction effects, results in Table (3) pointed out that sugar beet root length was significantly affected by the interaction between sowing dates and transplanting seedling age. The results showed that the differences between sowing sugar beet by dried seeds and transplanting by paper pots seedling of 25 days age methods as well as the differences between transplanting by paper pots seedling of 15 and/or 25 days age methods were insignificant when the plants grown on the $15^{\text {th }}$ of October. Meanwhile, the differences between each of the two methods reached the level of significance under $15^{\text {th }}$ September.

The highest root length of sugar beet roots was recorded with the combination between the $1^{\text {st }}$ sowing date $15^{\text {th }}$ September and transplanting by using paper pots of 15 days age $(33.99 \mathrm{~cm})$ followed by the dried seeds in the $1^{\text {st }}$ plant date $15^{\text {th }}$ September $(33.31 \mathrm{~cm})$.

\section{Root diameter.}

The available results showed that root diameter of sugar beet significantly responded to the difference in sowing dates. The earlier, the sowing date, the higher the root diameter. The pronounced influence of sowing date mainly due to the difference in the climatic conditions specially the temperature degree ( $31 \mathrm{C}$, Table 2 ) which accelerates the germination and plant growth consequently encouraged the plants to consist the appropriate foliage and good assimilation which reflected on root growth in terms of root diameter. Sowing sugar beet seedlings of 15 days age produced from paper pots attained superiority in sugar beet diameter over that recorded by the other seedling olds even sowing by the direct seeds. Once more, it could be observed that delaying the seedling age before transplanting decreased root thickness. El-Geddawy et al. (1997).

The results showed that root diameter similarly responded to micro-elements application with sugar beet length (Table 3), whatever zinc element was applied alone or in combination with boron element, surpassed both of unfertilized treatment or boron application only. The flourished influence of zinc alone or in mixture with boron on root diameter is mainly due to their effect on growth hormone production and sugar accumulation.

\section{Root fresh weight per plant.}

The collected data in (Table 4) appeared that delaying sowing date negatively and significantly affected root fresh weight. However, sowing sugar beet earlier $15^{\text {th }}$ September produced higher root fresh weight compared with $15^{\text {th }}$ October. Ramadan and Hassanin (1999) and Al-Jbawi (2000). The relative increase in the value of root fresh weight almost due to the enhanced influence of the early sowing date which 
exhibited a good canopy for solar energy trapping in turn high assimilation rate and finally good root weight.

Results given in Table (4) showed that using seedling of 15 days age for sowing beet recorded a significant effect on this trait compared with the other seedling aged 25 or 35 days or with that re-transplanted from thinning in the permanent field. The highest value of root fresh weight was obtained from the transplanted seedlings of 15 days age which was as same as that produced from sowing beet seeds by the dried seeds. The lowest value of root fresh weight was produced from the thinned plants. El-Geddawy et al. (1997).

Table 4. Effect of transplanting and soil application of boron and zinc on root and top fresh weights (kg/plant) in 2001-2002 and 2002-2003 seasons. (Combined over two seasons )

\begin{tabular}{|c|c|c|c|c|c|c|c|c|c|c|c|}
\hline \multirow{3}{*}{$\begin{array}{l}\text { Sowing } \\
\text { date }\end{array}$} & \multirow{3}{*}{$\begin{array}{l}\text { Sowing } \\
\text { method }\end{array}$} & \multicolumn{5}{|c|}{ Root fresh weight } & \multirow{2}{*}{\multicolumn{5}{|c|}{$\begin{array}{c}\text { Top fresh weight } \\
\text { Fertilization }\end{array}$}} \\
\hline & & \multicolumn{4}{|c|}{ Fertilization } & \multirow[b]{2}{*}{ Mean } & & & & & \\
\hline & & 0 & B & $\mathrm{Zn}$ & $B+Z n$ & & 0 & B & $\mathrm{Zn}$ & $B+Z n$ & Mean \\
\hline \multirow{5}{*}{$15 \mathrm{Sept}$} & 1 & 0.812 & 0.841 & 0.821 & 0.855 & 0.832 & 0.394 & 0.407 & 0.418 & 0.423 & 0.410 \\
\hline & 2 & 0.811 & 0.837 & 0.828 & 0.845 & 0.830 & 0.405 & 0.416 & 0.428 & 0.435 & 0.421 \\
\hline & 3 & 0.731 & 0.790 & 0.764 & 0.790 & 0.769 & 0.387 & 0.406 & 0.428 & 0.440 & 0.415 \\
\hline & 4 & 0.645 & 0.668 & 0.652 & 0.692 & 0.664 & 0.370 & 0.384 & 0.406 & 0.415 & 0.394 \\
\hline & 5 & 0.600 & 0.621 & 0.624 & 0.637 & 0.621 & 0.365 & 0.382 & 0.404 & 0.412 & 0.391 \\
\hline \multicolumn{2}{|c|}{ Mean } & 0.720 & 0.751 & 0.738 & 0.764 & 0.743 & 0.384 & 0.399 & 0.417 & 0.425 & 0.406 \\
\hline \multirow{5}{*}{15 Oct. } & 1 & 0.694 & 0.738 & 0.713 & 0.750 & 0.724 & 0.309 & 0.334 & 0.350 & 0.362 & 0.339 \\
\hline & 2 & 0.710 & 0.736 & 0.714 & 0.750 & 0.728 & 0.316 & 0.341 & 0.369 & 0.383 & 0.352 \\
\hline & 3 & 0.664 & 0.687 & 0.653 & 0.687 & 0.673 & 0.326 & 0.338 & 0.353 & 0.368 & 0.346 \\
\hline & 4 & 0.592 & 0.649 & 0.608 & 0.675 & 0.631 & 0.311 & 0.329 & 0.348 & 0.364 & 0.338 \\
\hline & 5 & 0.562 & 0.586 & 0.553 & 0.606 & 0.577 & 0.321 & 0.329 & 0.347 & 0.361 & 0.339 \\
\hline \multicolumn{2}{|c|}{ Mean } & 0.644 & 0.679 & 0.648 & 0.694 & 0.666 & 0.317 & 0.334 & 0.353 & 0.368 & 0.343 \\
\hline \multirow{5}{*}{$\begin{array}{l}\text { Mean of } \\
\text { sowing } \\
\text { method }\end{array}$} & 1 & 0.753 & 0.789 & 0.767 & 0.803 & 0.778 & 0.352 & 0.370 & 0.384 & 0.392 & 0.375 \\
\hline & 2 & 0.760 & 0.786 & 0.771 & 0.798 & 0.779 & 0.361 & 0.378 & 0.399 & 0.409 & 0.387 \\
\hline & 3 & 0.697 & 0.738 & 0.708 & 0.738 & 0.721 & 0.356 & 0.372 & 0.391 & 0.404 & 0.381 \\
\hline & 4 & 0.618 & 0.659 & 0.630 & 0.684 & 0.648 & 0.341 & 0.357 & 0.377 & 0.389 & 0.366 \\
\hline & 5 & 0.581 & 0.603 & 0.589 & 0.622 & 0.599 & 0.343 & 0.356 & 0.376 & 0.386 & 0.365 \\
\hline \multicolumn{2}{|c|}{ Mean } & 0.682 & 0.715 & 0.693 & 0.729 & - & 0.350 & 0.367 & 0.385 & 0.396 & - \\
\hline
\end{tabular}

LS.D at $0.05 \%$ level for:

Sowing date (D)

Transplanting seedling age (T)

$\begin{array}{ll}\text { Fertilization } & \text { (F) } \\ D \times T & \end{array}$

DXT

$D \times F$

$T X F$

DXTXF

$\begin{array}{cc}\text { S } & \text { S } \\ 0.016 & 0.0086 \\ 0.010 & 0.0053 \\ 0.022 & \text { N.S } \\ \text { N.S } & \text { N.S } \\ \text { N.S } & \text { N.S } \\ \text { N.S } & \text { N.S }\end{array}$

Results given in Table (4) revealed that application of micro-nutrients in terms of boron and zinc attained a relative and significant increase in the value of root fresh weight/plant. It could be observed that both of boron and/or zinc or their combination surpassed the unfertilized treatment with respect to root fresh weight/plant. Meanwhile, the results cleared that application of boron alone or in combination with zinc produced higher root fresh weight compared with zinc application alone. This 
finding may be indicate to the important role of boron element in respect to sugar accumulation as a transformation catalyst consequently. reflected on the weight of roots. Osman et al. (2003).

With regarded to the interactions effects, results obtained appeared that the $1^{\text {st }}$ degree interaction between sowing dates and transplanting seedling age attained a significant influence on the root fresh weight/plant. The results showed that the differences between sowing sugar beet by dried seeds and transplanting by paper pots seedling of 15 days age methods were insignificant when plants was grown on the two planting dates. The highest value of root fresh weight/plant $(0.832 \mathrm{~kg} /$ plant, 0.830 $\mathrm{kg}$ /plant successively) was recorded with Sowing by the direct seeds or by seedling of paper pots aged 15 days in the early sowing date $\left(15^{\text {th }}\right.$ September). The other combinations between the $1^{\text {st }}$ and $2^{\text {nd }}$ interactions were insignificant with respect to their effect on root fresh weight/plant.

\section{Top fresh weight per plant.}

The collected results showed that top weight/plant significantly responded to the earlier sowing date i.e., $15^{\text {th }}$ September, however, delaying sowing date to $15^{\text {th }}$ October decreased the value of this trait. This finding almost due to the suitable condition in terms of temperature (Table 1) which accelerates germination and plant growth. Effect of temperature (early sowing date) on this trait was reported by Dillon and Schmehl (1971) who mentioned that sugar beet in early date resulted in a closed leaf canopy sooner. The results obtained recorded a relative advantage for the transplanted seedling by using paper pot technique for the seedling of 15 and/or 25 days age followed by sowing the dry seeds. This result may be due to the controlled condition for the seedling grown in paper pot. The highest value of top fresh weight/plant was obtained by using seedling of 15 days age. The results obtained obviously show that the used two elements i.e., boron and or zinc recorded a statistical increase in the value of top fresh weight/plant whether applied singly or in combination with each other. The highest values of top fresh weight was recorded by the combination of zinc and boron fertilization ( $0.396 \mathrm{~kg} / \mathrm{plant})$ followed by zinc application ( $0.385 \mathrm{~kg} / \mathrm{plant})$ and finally by boron application $(0.367 \mathrm{~kg} /$ plant). The pronounced effect of these elements may be indicating to the important role of such elements in plant growth throughout their influence on the production of the enhanced substance such as plant growth substances.

Yield and its components:

1. Total root numbers per fed.

The collected data revealed that sowing sugar beet crop in the early sowing date i.e., $15^{\text {th }}$ September attained a relative advantage in the number of roots/fed (31007 root/fed). However, the differences between the two sowing dates were not enough 
to reach the level of significance. Regardless, the insignificant effect of sowing date on this trait, it could be noticed that the relative increase in roots number/fed, may be due to the enhanced effect of the higher temperature Table (2) in the $1^{\text {st }}$ sowing date compared with $2^{\text {nd }}$ date on the acceleration effect on seed germination. The relative importance of temperature on germination and growth has been reported by Abd ElAal (2001) who stated that under Egyptian conditions early planting date i.e., Mid September and Mid October favored germination percentage of sugar beet hills and consequently increased the final root. Results given in Table (5) sowed that sowing sugar beet by the transplanted seedlings of 15 days age significantly recorded the highest root number/fed (32476 roots/fed) compared with the various sowing date methods whether by using the dried seeds or by using the different transplanted seedlings at the different age

The results obtained pointed out that there were insignificant effects on this trait due to the studied microelement treatments. Concerning the interactions effect between the studied factors was that between transplanting seedling age and microelement fertilization. The results showed that transplanting sugar beet crop by using paper pot seedlings aged 15 days and the microelement (boron and zinc) together attained the highest root number/fed (32774 root/fed). This result may be indicate to the relative importance of paper pots as a tool to conserve sugar beet seedling throughout their growth and before transplanting them to the permanent soil consequently increasing plant number per unite area.

\section{Abnormal (branched) root percentage.}

Results given in Table (5) cleared that neither sowing date nor micro-element treatments affected the abnormal root percentage of sugar beet. On the contrary, the examined transplanting seedling old appeared a clear-cut effect on the percent values of abnormal sugar beet roots. The lowest value of abnormal root percentage (13.65 $\%$ ) was obtained when sugar beet crop was cultivated by using seedlings of 15 days age produced from paper pot technique followed by the normal method by using dry seeds (14.70\%). However delaying the transplanted seedling than 15 days gradually increased the abnormal percentage of sugar beet roots. This result is in line with that reported by El-Geddawy (1997) who found that sowing sugar beet by seedlings grown in paper pots at 2-leaf stage recorded the lowest value of branched roots compared with 4 and 6-leaf stage. This observation may be throw some light on the relative important of paper pot technique as a new applied technique for sugar beet cultivation to avoid many of un suitable condition for sugar beet growing such as soil disease, bad land preparation .. etc.

With respect to the interaction effects, of the studied factors, results obtained cleared that most of the various combination of the examined factors were 
insignificant. However, the only significant influence on this trait was that between sowing dates and transplanting seedling age. The results showed that the differences between sowing sugar beet by dried seeds and transplanting by paper pots seedling of 15 days age methods were insignificant when plants was grown on $15^{\text {th }}$ September. Meanwhile, the differences between each of the two methods reached the level of significance under $15^{\text {th }}$ October. Whatever, it could be noted that the lowest values of the abnormal percentage of sugar beet roots were produced from the cultivated seedling at 15 days age by using paper pot technique followed by sowing plants by dried seeds.

Table 5. Effect of transplanting and soil application of boron and zinc on total root numbers/fed and abnormal root percentage in 2001-2002 and 2002-2003 seasons. (Combined over two seasons)

\begin{tabular}{|c|c|c|c|c|c|c|c|c|c|c|c|}
\hline \multirow{3}{*}{$\begin{array}{l}\text { Sowing } \\
\text { date }\end{array}$} & \multirow{3}{*}{$\begin{array}{l}\text { Sowing } \\
\text { method }\end{array}$} & \multicolumn{5}{|c|}{ Total root numbers/fed } & \multirow{2}{*}{\multicolumn{5}{|c|}{$\begin{array}{c}\text { Abnormal root } \% \\
\text { Fertilization }\end{array}$}} \\
\hline & & \multicolumn{4}{|c|}{ Fertilization } & \multirow[b]{2}{*}{ Mean } & & & & & \\
\hline & & 0 & $B$ & $\mathrm{Zn}$ & $\mathrm{B}+\mathrm{Zn}$ & & 0 & B & $\mathrm{Zn}$ & $B+Z n$ & Mean \\
\hline \multirow{5}{*}{15 Sept } & 1 & 31120 & 30791 & 31407 & 31437 & 31189 & 12.84 & 13.09 & 15.21 & 13.50 & 13.66 \\
\hline & 2 & 32216 & 32544 & 32476 & 32975 & 32553 & 12.39 & 12.12 & 13.76 & 14.36 & 13.16 \\
\hline & 3 & 32097 & 31578 & 31491 & 31999 & 31791 & 32.74 & 36.14 & 33.57 & 34.17 & 34.16 \\
\hline & 4 & 31216 & 30930 & 30907 & 30792 & 30961 & 56.95 & 57.19 & 57.40 & 57.27 & 57.20 \\
\hline & 5 & 29128 & 28945 & 27881 & 28218 & 28543 & 75.63 & 74.66 & 75.33 & 74.50 & 75.03 \\
\hline \multicolumn{2}{|c|}{ Mean } & 31155 & 30958 & 30832 & 31084 & 31007 & 38.11 & 38.64 & 39.05 & 38.76 & 38.64 \\
\hline \multirow{5}{*}{15 Oct. } & 1 & 30908 & 30665 & 31021 & 31619 & 31053 & 15.29 & 15.03 & 15.75 & 16.89 & 15.74 \\
\hline & 2 & 32635 & 32150 & 32271 & 32572 & 32400 & 13.64 & 13.93 & 14.22 & 14.79 & 14.15 \\
\hline & 3 & 31529 & 31347 & 32332 & 32514 & 31930 & 31.55 & 30.96 & 32.69 & 35.09 & 32.57 \\
\hline & 4 & 31150 & 30806 & 31727 & 30741 & 31106 & 55.26 & 55.05 & 56.69 & 54.56 & 55.39 \\
\hline & 5 & 28499 & 28605 & 28135 & 28271 & 28378 & 74.54 & 77.27 & 75.98 & 74.84 & 75.65 \\
\hline \multicolumn{2}{|c|}{ Mean } & 30944 & 30709 & 31097 & 31143 & 30973 & 38.06 & 38.44 & 39.07 & 39.23 & 38.70 \\
\hline \multirow{5}{*}{$\begin{array}{l}\text { Mean of } \\
\text { sowing } \\
\text { method }\end{array}$} & 1 & 31014 & 30728 & 31214 & 31528 & 31121 & 14.07 & 14.06 & 15.48 & 15.19 & 14.70 \\
\hline & 2 & 32426 & 32332 & 32373 & 32774 & 32476 & 13.02 & 13.03 & 13.99 & 14.57 & 13.65 \\
\hline & 3 & 31813 & 31463 & 31911 & 32256 & 31861 & 32.15 & 33.55 & 33.13 & 34.63 & 33.36 \\
\hline & 4 & 31183 & 30868 & 31317 & 30766 & 31034 & 56.11 & 56.12 & 57.05 & 55.91 & 56.30 \\
\hline & 5 & 28813 & 28775 & 28010 & 28244 & 28460 & 75.09 & 75.96 & 75.66 & 74.67 & 75.35 \\
\hline \multicolumn{2}{|c|}{ Mean } & 31050 & 30833 & 30965 & 31113 & - & 38.09 & 38.54 & 39.06 & 38.99 & - \\
\hline $\begin{array}{l}\text { L.S.D at } 0 . \\
\text { Sowing da } \\
\text { Transplant } \\
\text { Fertllization } \\
\text { X T } \\
\text { XXF } \\
\text { TXF } \\
\text { DXTXF }\end{array}$ & $\begin{array}{l}5 \% \text { level } f \\
\text { (D) } \\
\text { is seedling } \\
\text { (F }\end{array}$ & (T) & 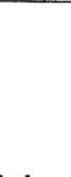 & & & $\begin{array}{c}5 \\
322.11 \\
\text { N.S } \\
\text { N.S } \\
\text { N.S } \\
598.60 \\
\text { N.S }\end{array}$ & & & & & $\begin{array}{c}\text { N.S } \\
0.990 \\
\text { N.S } \\
1.40 \\
\text { N.S } \\
\text { N.S } \\
\text { N.S }\end{array}$ \\
\hline
\end{tabular}

The collected results showed that sowing sugar beet early in the $15^{\text {th }}$ September attained a distinct increase in top yield/fed (12.61 ton/fed). This result indicates to the relative important of the prevalent condition for the rapid growth, which in turn reflected on organs plant growth. Delaying sowing date to $15^{\text {th }}$ October significantly reduced the top yield/fed. This reduction amounted by $18.73 \%$ than the earlier sowing date on $15^{\text {th }}$ September. This finding is in agreement with Azzazy (1998) . 
Results given in Table (6) showed that transplanting seedling old produced a statistical influence on the values of top yield/fed. Transplanting sugar beet seedling of 15 days age by using paper pot technique recorded the highest value of top yield/fed. ( 12.55 tons/fed) followed by the transplanted seedling of 25 days age then the sowing by dried seeds (12.12, 11.67 tons/fed successively). Increasing seedling age significantly decreased top yield/fed.

Table 6. Effect of transplanting and soil application of boron and zinc on top and root yields (tons/fed) in 2001-2002 and 2002-2003 seasons. (Combined over two seasons )

\begin{tabular}{|c|c|c|c|c|c|c|c|c|c|c|c|}
\hline \multirow{3}{*}{$\begin{array}{l}\text { Sowing } \\
\text { date }\end{array}$} & \multirow{3}{*}{$\begin{array}{l}\text { Sowing } \\
\text { method }\end{array}$} & \multicolumn{5}{|c|}{ Top yield tons/fed } & \multicolumn{5}{|c|}{ Root yield tons/fed } \\
\hline & & \multicolumn{4}{|c|}{ Fertilization } & \multirow[b]{2}{*}{ Mean } & \multicolumn{5}{|c|}{ Fertilization } \\
\hline & & 0 & B. & $\mathrm{Zn}$ & $B+Z n$ & & 0 & B & $\mathrm{zn}$ & $\mathrm{B}+\mathrm{Zn}$ & Mean \\
\hline \multirow{5}{*}{15 Sept } & 1 & 12.26 & 12.52 & 13.20 & 13.28 & 12.82 & 25.27 & 25.89 & 25.78 & 26.88 & 25.96 \\
\hline & 2 & 13.04 & 13.51 & 13.91 & 14.33 & 13.70 & 26.11 & 27.22 & 26.91 & 27.87 & 27.03 \\
\hline & 3 & 12.40 & 12.83 & 13.47 & 14.07 & 13.19 & 23.46 & 25.15 & 24.06 & 25.17 & 24.46 \\
\hline & 4 & 11.53 & 11.88 & 12.54 & 12.77 & 12.18 & 20.14 & 20.69 & 20.16 & 21.32 & 20.58 \\
\hline & 5 & 10.63 & 11.05 & 11.26 & 11.61 & 11.14 & 17.48 & 17.97 & 17.43 & 18.00 & 17.72 \\
\hline \multicolumn{2}{|c|}{ Mean } & 11.97 & 12.36 & 12.88 & 13.21 & 12.61 & 22.49 & 23.38 & 22.87 & 26.85 & 23.15 \\
\hline \multirow{5}{*}{15 oct. } & 1 & 9.55 & 10.24 & 10.84 & 11.43 & 10.52 & 21.46 & 22.66 & 22.14 & 23.73 & 22.50 \\
\hline & 2 & 10.31 & 10.94 & 11.92 & 12.48 & 11.41 & 23.15 & 23.64 & 23.04 & 23.43 & 23.57 \\
\hline & 3 & 10.25 & 10.59 & 11.39 & 11.96 & 11.05 & 20.90 & 21.52 & 21.11 & 22.33 & 21.47 \\
\hline & 4 & 9.70 & 10.12 & 11.02 & 11.17 & 10.50 & 18.44 & 20.04 & 19.27 & 20.76 & 19.63 \\
\hline & 5 & 9.13 & 9.41 & 9.77 & 10.17 & 9.62 & 16.02 & 16.74 & 16.06 & 17.13 & 16.49 \\
\hline \multicolumn{2}{|c|}{ Mean } & 9.79 & 10.26 & 10.99 & 11.44 & 10.62 & 20.00 & 20.92 & 20.32 & 21.68 & 20.73 \\
\hline \multirow{5}{*}{$\begin{array}{l}\text { Mean of } \\
\text { sowing } \\
\text { method }\end{array}$} & 1 & 10.90 & 11.38 & 12.03 & 12.36 & 11.67 & 23.37 & 24.27 & 23.96 & 25.30 & 24.23 \\
\hline & 2 & 11.68 & 12.23 & 12.92 & 13.40 & 12.55 & 24.63 & 25.43 & 24.97 & 26.15 & 25.30 \\
\hline & 3 & 11.33 & 11.71 & 12.44 & 13.01 & 12.12 & 22.18 & 23.33 & 22.58 & 23.75 & 22.96 \\
\hline & 4 & 10.61 & 11.00 & 11.78 & 11.97 & 11.34 & 19.29 & 20.36 & 19.71 & 21.04 & 20.10 \\
\hline & 5 & 9.88 & 10.23 & 10.52 & 10.89 & 10.38 & 16.74 & 17.35 & 16.75 & 17.56 & 17.10 \\
\hline \multicolumn{2}{|c|}{ Mean } & 10.88 & 11.31 & 11.94 & 12.33 & - & 21.24 & 22.15 & 21.59 & 22.76 & - \\
\hline
\end{tabular}

L.S.D at $0.05 \%$ level for:

Sowing date (D)

Transplanting seedling age $(T)$

Fertilization (F)

DXT

$D X F$

$T X F$

DXTXF

$\begin{array}{cc}\text { S } & \text { S } \\ 0.283 & 0.553 \\ 0.189 & 0.340 \\ 0.401 & 0.782 \\ \text { N.S } & \text { N.S } \\ \text { N.S } & \text { N.S } \\ \text { N.S } & \text { N.S }\end{array}$

Regarding the influence of micro-elements on top yield/fed., the available data revealed that application of boron and/or zinc element or their combination produced a significant increase in the value of top yield/fed., compared with check treatment (unfertilized treatment). However, it could be noticed that even between the examined elements i.e., boron and zinc the difference was significant. Application of zinc alone or in combination with boron attained the highest value of top yield/fed. Elwan et al. (2001). 
Concerning the influence of the interaction between the studied factors, results obtained pointed out that the interaction was that between sowing date and transplanting seedling age. The result showed that the differences between sowing sugar beet by dried seeds and transplanting by paper pots seedling of 25 days age methods were insignificant when plants was grown on $15^{\text {th }}$ of September. Meanwhile, the differences between each of the two methods reached the level of significance under $15^{\text {th }}$ October. Moreover the differences between sowing sugar beet by dried seeds and/or transplanting by paper pots seedling of 35 days age methods and difference between transplanting by paper pots seedling of 15 and/or 25 days age methods were insignificant when plants was grown on $15^{\text {th }}$ October.

The highest values of top yield/fed (13.70 tons/fed.) was recorded by sowing sugar beet seedling of 15 days age at the $15^{\text {th }}$ of September.

\section{Root yield ton per fed.}

Data given showed that the earlier the sowing date ( $15^{\text {th }}$ September), the higher the root yield ( 23.15 tons/fed) and vice versa, the later, the sowing date $\left(15^{\text {th }}\right.$ October), the lower the root yield (20.73 tons/fed). Abd El-Aal (2001) and Abou Salama and El-Sayed (2001). The pronounced effect of sowing date mainly due to the relative advantage of the appropriate temperature prevailed at the earlier sowing date which accelerate the assimilation rate from the assimilator organ i.e., top (leaves), consequently such condition enhanced the relative growth rate and root yield.

Data collected in Table (6) revealed that transplanting seedling age significantly affected root yield/fed. The highest root yield of sugar beet ( 25.30 tons/fed) was produced when sugar beet seedling were transplanted at 15 days age. This observation was true compared with the others seedling age as well as in comparison with that of the thinned seedling. However, it could be noted that sowing sugar beet crop by the usual method (dried seeds). Followed transplanting seedling at 15 days age treatment, which attained superiority over the conventional method too.

The relative advantage of cultivation sugar beet roots by the transplanted seedling may be due to the suitable condition of growth in the paper pot away from any damage effect such as bacteria or the rot is fungi which damage plenty of roots at seedling stage which in turn negatively reflected on the final root yield at harvest. Abd El-Gawad et al. (2000).

Results given in Table (6) cleared that yield of sugar beet roots statistically responded to the examined micro-elements. It could be noted that application of boron alone or in combination with zinc element gave the highest root yield/fed $(22.15$ and 22.76 tons/fed, respectively) compared with unfertilized treatment ( 21.24 tons/fed) or zinc alone ( 21.59 tons/fed). The effective role of the micro-element on 
root yield mainly due to the enhanced role of boron element with respect to its effect on sugar translocation from leaves to roots which in turn reflected on root yield. The interaction effect of the studied factors revealed that the highest value of root yield ( 26.15 tons/fed) was recorded when sugar beet crop was cultivated by using seedling of 15 days age with the treatment of the combination between boron and zinc elements and the lowest value ( 16.02 ton/fed) was recorded when sowing by the thinned seedling on $15^{\text {th }}$ October.

\section{Sugar recovery percentage.}

Data given in Table (7) revealed that sowing sugar beet early on $15^{\text {th }}$ September attained a considerable value of sugar recovery percentage. The increases in the value of sugar recovery percentage as a result to the early sowing date reach to $16.7 \%$ over that of the late sowing date. The relative response of the early sowing date may be due to the pronounced effect on sucrose and impurities percentages. The influence of sowing date on juice quality has been reported by Al-Jbawi (2000). With respect to the influence of transplanting seedling age on sugar recovery percentage, the available data pointed and that sowing sugar beet by the transplanted seedling aged 15 days and/or by the dried seeds produced the highest significant effect on sugar recovery percentage $(13.78 \%, 13.56 \%$ respectively). However, it could be noted that sowing by transplanted seedling of 15 days age surpassed all the other transplanted seedlings. This result may be due to the relative advantage of rapid growth consequently the early improve in juice quality.

Concerning the effect of micro-elements fertilization on sugar recovery percentage, The results obtained assured that boron element plays a direct effect on sugar recovery percentage, fertilizing sugar beet plants by the recommended dose of boron alone ( $0.5 \mathrm{~kg}$ boron/fed as a soil application) or in combination with the recommended dose (4 $\mathrm{kg}$ zinc/fed as a soil application) (13.22\%, $13.41 \%$ respectively) surpassed the check treatment unfertilized treatment (12.59\%) as well as zinc treatment $(12.48 \%)$. The above-mentioned results clearly show the effective role of boron element in sugar translocation consequently juice quality in terms of sugar recovery percentage.

The interaction between sowing dates and the age of the transplanted seedling had a significant effect on sugar recovery percentage. The result obtained revealed that the differences between sowing sugar beet by dried seeds or transplanting by paper pots seedling of 15 days age methods were insignificant when sugar beet plants were grown on $15^{\text {th }}$ October. Meanwhile, the differences between each of the two methods reached the level of significance under $15^{\text {th }}$ of September. Moreover the differences between sowing sugar beet by dried seeds and transplanting 
by paper pots seedling of 25 days age methods were insignificant on $15^{\text {th }}$ September and significant on $15^{\text {th }}$ October. However, the others various combinations between the studied factors did not reach the level of significance.

The highest values of sugar recovery was recorded when sugar beet crop was sown by the transplanted seedling aged 15 days $(13.78 \%)$ or by the dried seeds (13.56 \%) on $15^{\text {th }}$ September.

\section{Sugar yield ton per fed.}

Results given in Table (7) throw some light around the relative advantage of the choused factors on sugar production. Figures illustrated pointed out that growing sugar beet early of season ( $15^{\text {th }}$ September) attained a broached increase in the values of sugar production amounted by (21.94\%) over that of $15^{\text {th }}$ October. This result is in line with the natural condition of sugar beet growing in the various growth stages. Growing sugar beet in early of season (August and September) save a sufficient light and solar energy which acculturate germination and the vegetative growth consequently give the plant grow the low temperature needed (throughout maturity stage i.e., December, January, February and March) to storage sugar. Abd ElAal (2001)

Concerning the influence of transplanting seedling age on sugar yield, the avail data in Table (7) cleared that there were significant differences between the studied transplanting seedlings old with respect to their effect on sugar yield. Growing sugar beet crop by using the transplanted seedling of 15 days age attained a distinct increase in sugar yield/fed reached to 0.22 ton of sugar/fed compared with the common method of sugar beet sowing (dried seeds). Once more, it could be noted that delaying the transplanted seedling to 25 or 35 days and or by the thinned seedling lowered sugar yield by $0.57,1.18$ and 1.67 tons/fed, respectively compared with the transplanting seedling of 15 days age. The above mentioned results reassure that the pronounced decrease in the sugar yield mainly due to the wrong use for the thinned seedling in the re-transplanting sugar beet field by such seedling. El-Debaby et al. (2003). Regarding the effect of the studied micro-elements on sugar yield, the collected figures pointed out that both of boron or zinc elements singly or in combination with each other attained a broached increase in sugar yield. The highest value of increase amounted by 0.41 -ton sugar/fed. When the two elements were added together compared with the check treatment (control).

The result obtained showed that the differences between each of (transplanting by paper pots seedling of 15 days age or by seedling resulted from the permanent field at thinning time methods) and/or (sowing sugar beet by dried seeds, or by seedling resulted from the permanent field at thinning time methods) and/or 
between (transplanting by paper pots seedling of 15 and/or 35 days age methods) were more distinguished and significant under $15^{\text {th }}$ September than that of $15^{\text {th }}$ October.

The highest sugar yields 4.77 tons/fed was recorded when the transplanted seedling of 15 days age was sown in $15^{\text {th }}$ September and the lowest value (2.31 ton/fed) was found when sugar beet crop was sown on $15^{\text {th }}$ October by using the thinned seedling resulted from the permanent field at thinning time. However, the differences between the various combinations of the studied factors were not enough to reach the level of significance.

Table 7. Effect of transplanting and soil application of boron and zinc on in sugar recovery percentage and sugar yield (tons/fed) 2001-2002 and 2002-2003 seasons. (Combined over two seasons )

\begin{tabular}{|c|c|c|c|c|c|c|c|c|c|c|c|}
\hline \multirow{3}{*}{$\begin{array}{l}\text { Sowing } \\
\text { date }\end{array}$} & \multirow{3}{*}{$\begin{array}{l}\text { Sowing } \\
\text { method }\end{array}$} & \multicolumn{5}{|c|}{ Sugar recovery \% } & \multicolumn{5}{|c|}{ Sugar yield tons/fed } \\
\hline & & \multicolumn{4}{|c|}{ Fertilization } & & \multicolumn{5}{|c|}{ Fertilization } \\
\hline & & 0 & B & $\mathrm{Zn}$ & $B+Z n$ & Mean & 0 & B & $\mathrm{Zn}$ & $B+Z n$ & Mean \\
\hline \multirow{5}{*}{$15 \mathrm{Sept}$} & 1 & 14.47 & 15.13 & 14.52 & 15.32 & 14.86 & 4.36 & 4.60 & 4.47 & 4.88 & 4.57 \\
\hline & 2 & 14.45 & 15.18 & 14.40 & 15.50 & 14.88 & 4.48 & 4.89 & 4.63 & 5.06 & 4.77 \\
\hline & 3 & 13.42 & 13.92 & 13.47 & 14.32 & 13.78 & 3.81 & 4.18 & 3.91 & 4.26 & 4.04 \\
\hline & 4 & 12.96 & 13.25 & 12.65 & 13.27 & 13.03 & 3.19 & 3.33 & 3.13 & 3.46 & 3.28 \\
\hline & 5 & 12.91 & 12.97 & 12.81 & 13.41 & 13.03 & 2.70 & 2.87 & 2.72 & 2.92 & 2.80 \\
\hline \multicolumn{2}{|c|}{ Mean } & 13.64 & 14.09 & 13.57 & 14.36 & 13.92 & 3.71 & 3.97 & 3.77 & 4.12 & 3.89 \\
\hline \multirow{5}{*}{15 oct. } & 1 & 12.02 & 12.65 & 11.39 & 12.97 & 12.26 & 3.27 & 3.60 & 3.37 & 3.83 & 3.51 \\
\hline & 2 & 12.23 & 13.23 & 12.01 & 13.23 & 12.68 & 3.70 & 3.84 & 3.53 & 4.00 & 3.77 \\
\hline & 3 & 11.87 & 12.84 & 11.63 & 12.81 & 12.29 & 3.21 & 3.43 & 3.20 & 3.61 & 3.36 \\
\hline & 4 & 10.59 & 11.59 & 11.14 & 11.70 & 11.26 & 2.63 & 3.04 & 2.76 & 3.18 & 2.90 \\
\hline & 5 & 10.93 & 11.45 & 10.77 & 11.56 & 11.18 & 2.31 & 2.46 & 2.31 & 2.56 & 2.41 \\
\hline \multicolumn{2}{|c|}{ Mean } & 11.53 & 12.35 & 11.39 & 12.45 & 11.93 & 3.02 & 3.27 & 3.03 & 3.43 & 3.19 \\
\hline \multirow{5}{*}{$\begin{array}{l}\text { Mean of } \\
\text { sowing } \\
\text { method }\end{array}$} & 1 & 13.25 & 13.89 & 12.96 & 14.15 & 13.56 & 3.81 & 4.10 & 3.92 & 4.35 & 4.05 \\
\hline & 2 & 13.34 & 14.21 & 13.20 & 14.36 & 13.78 & 4.09 & 4.36 & 4.10 & 4.53 & 4.27 \\
\hline & 3 & 12.65 & 13.38 & 12.55 & 13.57 & 13.04 & 3.51 & 3.81 & 3.56 & 3.93 & 3.70 \\
\hline & 4 & 11.77 & 12.42 & 11.90 & 12.49 & 12.15 & 2.91 & 3.18 & 2.94 & 3.32 & 3.09 \\
\hline & 5 & 11.95 & 12.18 & 11.79 & 12.49 & 12.10 & 2.50 & 2.67 & 2.51 & 2.74 & 2.60 \\
\hline & 12.59 & 13.22 & 12.48 & 13.41 & - & 3.36 & 3.62 & 3.40 & 3.77 & - \\
\hline
\end{tabular}

L.S.D at $0.05 \%$ level for:

Sowing date (D)
Transplanting seedling age (T)
Fertilization (F)
DXT
DXF
TXF
DXTXF

$\mathrm{S}$

0.23

0.24

0.33

N.S

N.S

N.S
$\mathrm{S}$

0.105

0.075

0.148

N.S

N.S

N.S 


\section{REFERENCES}

1. Abd El-Aal, A. M. 2001. Abundance of weeds and efficiency of weed control programs in sugar beet fields in relation to planting date. Ph. D. Fac. of Agric., Ain Shams Univ.

2. Abd El-Gawad, A. A., H. Kh. Hassan and W. M. Hassany. 2000. Transplanting technique to adjust plant stand of sugar beet under saline conditions. Proc. $9^{\text {th }}$ Agronomy Conf., Minufiya Univ., 550-562.

3. Abou Salama, A. M. and S. I. El -Sayed. 2001. Studies on some sugar beet cultivars under middle Egypt conditions. 1-Response to planting and harvesting dates. Assiut J. Agric. Sci. 31 (1): 137-159.

4. Al-Jbawi, Entessar, M. 2000. Performance of some sugar beet genotypes under different environments. M. Sc. Thesis, Fac. of Agric. Cairo. Univ., Egypt.

5. Azzazy, N.B. 1998. Effect of sowing date, irrigation interval and nitrogen fertilization on yield and quality of sugar beet under upper Egypt conditions. Egypt J. Agric. Res. 76 (3): 1099-1113.

6. Dillon, M. A. and W. R. Schmehl 1971. Sugar beet as influenced by row width, nitrogen fertilization and planting date. J. Amer. Soc. Sugar Beet Technol. 16: 585-594.

7. Draycott, A.P. 1993. Nutrition, 239-278. In: D.A. Cooke and R.K. Scott. The Sugar Beet Crop. Chapman \& Hall, 2-6 Boundary Row, London, SEI 8 HN, UK.

8. El-Debaby A., S. I. Hefhi, EIS. H. M., EL-Kholi, M. MA and R. T. Behairy 2003. Improvement of sugar beet through transplanting technology. $10^{\text {th }}$ National Conf. of Agronomy, Fac. of Environ. Agric. Sci., EL Arish, Suez Canal Univ., Egypt. Soc. Agron. 1-10 Oct., 2003.

9. El-Geddawy, I. H., S.S. Zalat and Laila M. Saif 1997. Transplanting sugar beet seedlings with relation to yield and quality of sugar beet.J. Agric. Sci. Mansoura Univ., 22 (2): 361-368.

10. Elwan, I. M, Ramadan Zeinab M. and Shafika Nasr M. 2001. Effect of copper and zinc fertilizer application on growth, chemical and biochemical contents of sugar beet plants.Zagazig J. Agric. Res., 28 (2): 367-380.

11. Le-Clerg, L., W. H. Leonard and G. A. Clark. 1966. Field Plot Technique.Burgess Pub. Comp. Minnesota, USA, pp 1-373.

12. Osman, A. M. H., G. S. El-Sayed, M. S. H. Osman and K. S. El-Sogheir (2003). Soil application of some micro-elements with relation to yield and quality of sugar beet varieties (Beta vulgaris L.).Ann. Agric. Sci., Moshtohor, 41 (3): 1135-1152.

13. Ramadan, B. S. H. and M. A. Hassanin. 1999. Effect of sowing date on yield and quality of some sugar beet (Beta Vulgaris L.) Varieties. J. Agric. Sci. Mansoura Univ., 24(7): 3227-3237.

14. Saif, Laila M. 1991.Yield and quality of sugar beet as affected by nitrogen sources and rate of some microelements in Kafer El-sheikh. Ph.D. Thesis, Fac. of Agric. Ain Shams Univ.

15. Snedecore, G. W. and W. G. Cochran. 1967. Statistical Method. $6^{\text {th }}$ Ed., Iowa State Univ. Press, Ames., Iowa, USA. 


\section{الثتل باستخدام تقتية الأصص الورقية والتغذية بالعناصر الصغرى وعلاقة ذلك بحاصل ومكونات بنجر السكر المنزرع في مواعيد مختلفة}

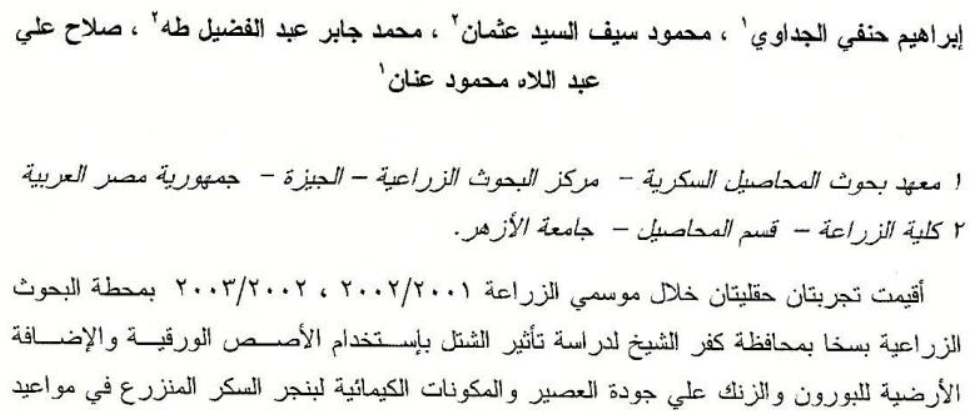

مختلفة.

اشتملت كل تجربة علي عشرين معاملة تمثل التو افق بين خمسة طرق لززراعــة بنجـر الســكر

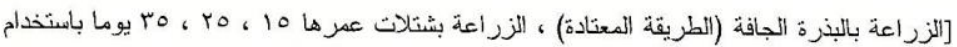

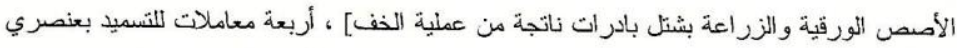

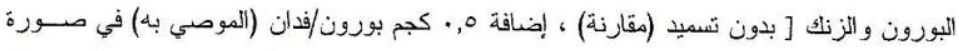

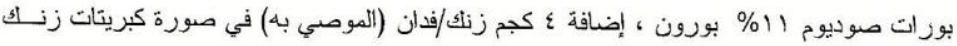

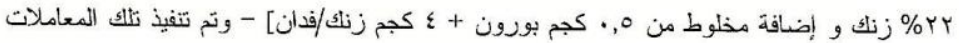

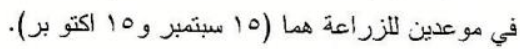

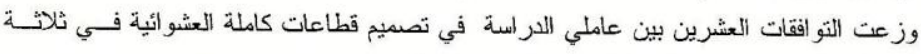

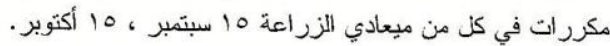

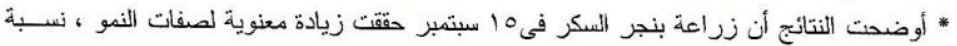

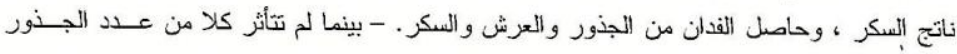

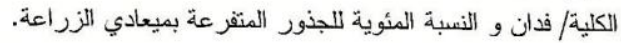

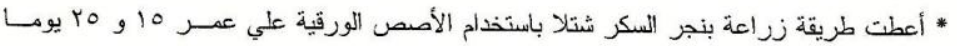

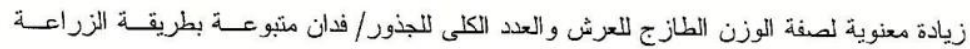
بالبذرة مباشرة. * أظهرت النتائج أن إضافة عنصر الزنك منفردا أو مضافا إلي عنصر البوزرون قد نتج عنها زيادة

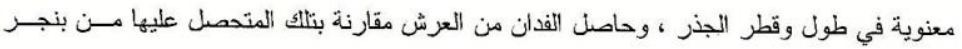
السكر غير المسمد أو المسمد بالبورون منفردا.

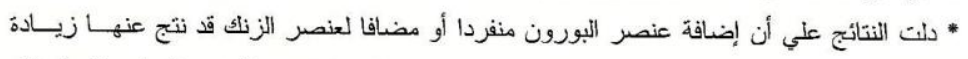

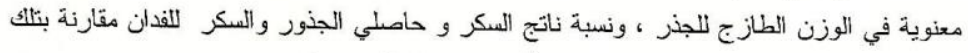

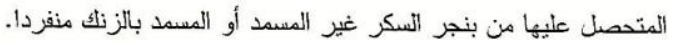

